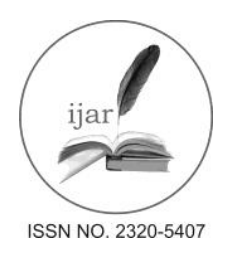

Journal homepage: http://www.journalijar.com
Journal DOI: $10.21474 /$ IJAR01

INTERNATIONAL JOURNAL

OF ADVANCED RESEARCH

RESEARCH ARTICLE

\title{
ISOLATION AND PARTIAL CHARACTERIZATION OF LECTINS FROM INDIAN VARIETIES OF LEGUMINOUS PLANTS.
}

\author{
Dr. Radiya Pacha-Gupta*, Dr. Priya Sundarrajan, Fiona DeSouza, Kriti Nagrath, Lydia Tauro, Pritesh \\ Krishnakumar, Runjhun Srivastava, Tanvi Sinha.
}

Department of Life Science and Biochemistry, St. Xavier's College, Mumbai - 400 001, India.

\section{Manuscript Info}

Manuscript History:

Received: 15 March 2016

Final Accepted: 12 May 2016

Published Online: May 2016

Key words:

Lectins, haemagglutination, $\mathrm{ABO}$ blood group, leguminous plants, Rajma, Kulith.

*Corresponding Author

Dr. Radiya Pacha-Gupta.

\begin{abstract}
Lectins are glycoproteins of nonimmune origin derived from plants, microbes, or animal sources. Some plant lectins agglutinate various blood groups of erythrocytes and are therefore called phytohaemagglutinins. In the present study, 21 seeds of Indian variety of plants were used to extract and characterize lectins for their haemagglutination activity against the human ABO blood group antigens. Crude extracts of lectins were prepared using three different extraction methods. From the 21 seed extracts tested, 10 of them showed positive haemagglutination. Rajma (Phaseolus vulgaris var) and kulith (Dolichos biflorus) lectin extracts were used for further characterization. Hapten-inhibition assays using mono and disaccharides showed specificity for $\mathrm{N}$-acetyl galactosamine for rajma lectin extract, whereas kulith lectin did not show any sugar specificity. Partial purification of these extracts by ammonium sulphate fractionation followed by SDSPAGE showed several protein bands. In haemagglutination assays, kulith lectin extracts showed agglutination only with blood group A, whereas rajma extracts agglutinated RBCs from $\mathrm{A}, \mathrm{B}$, and $\mathrm{O}$ blood groups. Further, using the kulith extract, negative haemagglutination was observed in two out of nine samples of blood having the A antigen on its membrane. Human blood group A has several subtypes, the major being A1 and A2. It is known that Dolichos biflorus has A1 specific lectins (Nance, 1986; Sharon and Liz., 2004). It is possible that the lectin extracted from the Indian variety of Dolichos biflorus (kulith) is an A1 specific lectin. Purified A1-specific lectin from kulith has the potential to be used for commercial blood typing differentiating A1 from other subtypes of human blood group A.
\end{abstract}

Copy Right, IJAR, 2016,. All rights reserved.

\section{Introduction:-}

Lectins are carbohydrate-binding proteins present in plants, animals and microbes (Slifkin et al., 1990). These are glycoproteins with molecular weights ranging between $60 \mathrm{kDa}$ to $100 \mathrm{kDa}$ (Pereira et al., 2015). Plant lectins are commonly derived from seeds, leaves, tubers and stems (Eshdat et al., 1978). Several plant species have been used to purify and characterize lectins (Da Silva et al., 2001; Ceccatto et al., 2002; Ali et al., 2013). The ability of plant lectins to cause haemagglutination of selective erythrocytes has led to the isolation and characterization of these glycoproteins (Grant et al., 1995; Sharon et al., 2004). Lectins act as a bridge and bind to the carbohydrate moieties on two different RBCs and hence give rise to the 'clumping of erythrocytes' (Sharon et al., 1972; Lu et al., 2014). The specificity of the lectin is due to its affinity to bind to a specific carbohydrate present on the plasma membrane of erythrocytes (Mandrell et al., 1988). Most lectins in plant species are not ABO blood type specific and only a few edible plants contain lectins that are specific for blood group antigens (Ingram et al., 1988). Lectins from stems and leaves do not show haemagglutination properties. 
Lectins are generally classified into five major groups according to their affinity for reversible interactions with different carbohydrates: (i) glucose / mannose, (ii) galactose and $\mathrm{N}$-acetyl-D-galactosamine, (iii) $\mathrm{N}$-acetyl glucosamine, (iv) L-fucose and (v) sialic acids (Damjanov, 1987). Within the plant body, lectins play an active role in transport of carbohydrates and in the formation of symbiotic associations with rhizobia to facilitate the formation of root nodules (Etzler, 1986; Lis et al., 1986).

The objective of this study was to (1) extract lectins from seeds of Indian plant varieties using different extraction procedures, (2) determine the optimum conditions of $\mathrm{pH}$ and temperature for extraction, (3) determine the haemagglutination activity using ABO blood group antigens, qualitatively and quantitatively, (4) determine sugar specificity of the extracted lectins and (5) analyze the lectin proteins by ammonium sulphate fractionation followed by PAGE. The primary focus was to identify lectins which could be used in diagnostic kits for human ABO blood group analysis.

\section{Materials and methods:-}

Extraction of Lectins:-

Dehulled seeds of a total of fifteen leguminous and non-leguminous plants were finely ground and lectins were extracted by the following 3 different methods:

Method1:- $5 \mathrm{~g}$ of dehulled seeds were finely ground and stirred with the following buffers added one by one in the following order: (a) $10 \mathrm{~mL} 0.1 \mathrm{M}$ Glycine- $\mathrm{HCl}(\mathrm{pH} 2.6)$ made in $0.1 \mathrm{M} \mathrm{NaCl}$, (b) $10 \mathrm{~mL} 0.1 \mathrm{M}$ Na-Acetate (pH 4.0) made in $0.1 \mathrm{M} \mathrm{NaCl}$, (c) $10 \mathrm{~mL} 0.1 \mathrm{M}$ Tris- $\mathrm{HCl}$ (pH 6.0) made in $0.1 \mathrm{M} \mathrm{NaCl}$, (d) $10 \mathrm{~mL}$ of $0.1 \mathrm{M}$ Na-Borate, (pH 8.0) made in $0.1 \mathrm{M} \mathrm{NaCl}$ and (e) $10 \mathrm{~mL}$ of $0.1 \mathrm{M} \mathrm{Na}$-Borate $(\mathrm{pH} 10.0)$ made in $0.1 \mathrm{M} \mathrm{NaCl}$. The final $\mathrm{pH}$ of the solutions was 6.9. The suspensions were left at room temperature for 3 hours and centrifuged at 10,000×g for 20 minutes at $7^{\circ} \mathrm{C}$. The clear supernatants were used to determine the haemagglutination activity of the lectins.

Method2:- 30g of seed powder was soaked in $100 \mathrm{~mL}$ of $0.15 \mathrm{M} \mathrm{NaCl}$. The resulting suspensions were maintained for 3 hours at room temperature or overnight at $4^{\circ} \mathrm{C}$. These were further centrifuged at $10,000 \times \mathrm{g}$ for 30 minutes at $7^{\circ} \mathrm{C}$. The clear supernatants were used to determine the hemagglutinating activity of the lectins.

Method3:- Seeds were powered and 5g of powder was weighed and used. $100 \mathrm{~mL}$ of $0.04 \mathrm{M}$ Glycine-HCl buffer $(\mathrm{pH}$ 2.2) was added and the mixture was stored for 16 hours at $1^{\circ} \mathrm{C}$ [flour to buffer ratio of 1:20]. The resultant mixture was centrifuged at $10,000 \times \mathrm{g}$ for 20 minutes at $7^{\circ} \mathrm{C}$. Clear supernatant thus obtained was stored at $5^{\circ} \mathrm{C}$. The clear supernatants were used to determine the hemagglutinating activity of the lectins.

\section{Collection of fresh blood:-}

$5 \mathrm{~mL}$ of blood was collected from healthy individuals (18 to 50 years of age) in a sterile syringe, (consent was taken from all individuals). The collected blood was mixed with $0.05 \mathrm{~g}$ of EDTA and stored at $4^{\circ} \mathrm{C}$. These blood samples were used to carry out qualitative haemagglutination assays.

\section{Preparation of 4\% R.B.C. Suspension:-}

The collected blood was centrifuged at $3000 \times \mathrm{g}$ for 10 minutes at room temperature. $4 \mathrm{~mL}$ of the pellet was suspended in $96 \mathrm{~mL}$ of $0.15 \mathrm{M} \mathrm{NaCl}$ (to yield a $4 \% \mathrm{RBC}$ suspension). This suspension was then used for the quantitative haemagglutination assay.

\section{Haemagglutination Assays:-}

* Qualitative Haemagglutination Assay:-

$50 \mu \mathrm{l}$ of the extract was mixed with equal volume of blood of groups A, B and O separately. The positive controls used were the commercial monoclonal antibodies against the respective $\mathrm{ABO}$ blood group antigens. The negative control used was $0.15 \mathrm{M} \mathrm{NaCl}$. Agglutination of blood was observed under a light microscope.

\section{* Quantitative Haemagglutination Assay:-}

Serially diluted lectin extract was mixed with $4 \%$ RBC suspension. The tubes were incubated at $37 \mathrm{C}$ for 30 min and observed for agglutination under 10x magnification by light microscope. The reciprocal of the last dilution showing positive agglutination is the titre expressed as hemagglutination units (HU). 


\section{Hapten-Inhibition Assay:-}

The carbohydrate binding specificity of the lectin was estimated by the ability of a series of single sugars to inhibit the hemagglutinating of human erythrocytes and the lowest concentration of the sugar giving full inhibition was determined. $0.5 \mathrm{M}$ sugar solutions were made in $2 \mathrm{~mL}$ distilled water. Sugars used were D-Galactose, DGlucosamine, Maltose, Fructose, Sucrose, Glucose, Fucose and N-Acetyl Galactosamine. $2 \mathrm{~mL}$ of each sugar solution (of $0.5 \mathrm{M}$ concentration) was serially diluted upto $0.03125 \mathrm{M}$ for lectin extracts from kulith, and up to $0.025 \mathrm{M}$ for rajma lectin extract. $0.25 \mathrm{~mL}$ of each of these dilutions was mixed with $0.25 \mathrm{~mL}$ of lectin (diluted $1: 10$ with $0.15 \mathrm{M} \mathrm{NaCl}$ ) extracted with Method 2. The mixture was incubated for 30 minutes at $37{ }^{\circ} \mathrm{C} .0 .5 \mathrm{~mL}$ of a $4 \%$ R.B.C suspension was added and the mixture was incubated for another 30 minutes at $37^{\circ} \mathrm{C}$. The occurrence of haemagglutination was checked under 10x magnification by light microscopy.

\section{Protein Estimation of Crude Extracts:-}

Biuret method was used to estimate the protein content of the crude kulith and rajma extracts. Standard protein used was egg albumin $(2 \mathrm{mg} / \mathrm{mL}$ to $10 \mathrm{mg} / \mathrm{mL})$. Absorbance was measured at $\lambda=540 \mathrm{~nm}$.

\section{Semipurification of Lectins:-}

* Ammonium Sulfate Fractionation:-

Aliquots of the rajma lectin extract prepared by Method 3 were used for ammonium sulphate fractionation. Fractions $0-25 \%, 25-50 \%, 50-75 \%$ and $75-90 \%$ were obtained. Protein concentration and haemagglutination activity was assayed in all the fractions.

\section{* SDS-PAGE:-}

The proteins in the various extracts were separated using PAGE (5\% stacking gel and 15\% resolving gel). The gel was electophoresed at $100 \mathrm{~V}$ for $2 \mathrm{hrs}$ at room temperature (Sambrook et al., 2001).

\section{Results:-}

Qualitative Analysis of Haemagglutination Activity:-

This assay was carried out with various crude lectin extracts obtained by different extraction procedures as described above.

Extraction Method 1:- Using this method jack bean and rajma extracts showed positive haemagglutination with erythrocytes from blood groups A, B and $\mathrm{O}$ (Table 1, Fig 1). The remaining eight lectin extracts showed nonreactivity to all blood groups (Table 1, Fig 2).

Table 1: Results for qualitative haemagglutination assay using lectins extracted by Method 1. '+' sign is indicative of haemagglutination, ' ++ ' and ' +++ ' signs are indicative of relatively greater haemagglutination, ' - ' sign is indicative of negative haemagglutination.

\begin{tabular}{|c|c|c|c|c|}
\hline \multicolumn{6}{|c|}{ Qualitative analysis of haemagglutination by lectins extracted by Method 1 } \\
\hline Common name & Scientific name(ref.13) & Blood Group A & Blood Group B & Blood Group O \\
\hline Jack bean & Conavalia ensiformis & ++ & ++ & ++ \\
\hline Rajma & Phaseolus vulgaris var. & +++ & +++ & +++ \\
\hline Chana [Brown] & Cicer arientinum var. & - & - & - \\
\hline Chana [Kabuli] & Cicer arientinum var. & - & - & - \\
\hline Kulith & Dolichos biflorus & - & - & - \\
\hline Black-eyed pea (chawli) & Vigna unguiculata & - & - & - \\
\hline Matki & Cicer arientinum var. & - & - & - \\
\hline Moong [Yellow] & Vigna radiate & - & - & - \\
\hline Corn & Zea mays everta & - & - & - \\
\hline Tur Dal & Lens culinaris & - & & - \\
\hline
\end{tabular}


Extraction Method 2:- Using Method 2, extracts of white kidney beans, pea and vaal exhibited haemagglutination activity with erythrocytes from blood groups A, B and O (Table 2). Only extract from kulith seeds showed hemagglutination with blood group A indicating a specificity for the sugars present for blood group A. Hence, it is possible to use extracts from kulith for blood typing analysis.

Table 2: Results for qualitative haemagglutination assay using lectins extracted by Method 2. '+' sign is indicative of positive haemagglutination, ' ++ ' and ' +++ ' signs are indicative of relatively greater haemagglutination, ' - ' sign is indicative of negative haemagglutination.

\begin{tabular}{|c|c|c|c|c|}
\hline \multicolumn{5}{|c|}{ Qualitative analysis of haemagglutination by lectins extracted by Method 2 } \\
\hline Common name & Scientific name(ref.13) & $\begin{array}{c}\text { Blood Group } \\
\text { A }\end{array}$ & $\begin{array}{c}\text { Blood Group } \\
\text { B }\end{array}$ & $\begin{array}{c}\text { Blood Group } \\
\text { O }\end{array}$ \\
\hline Kidney Bean [White] & Phaseolus vulgaris var. & ++ & ++ & ++ \\
\hline Kulith & Dolichos biflorus & + & - & - \\
\hline Pea & Pisum sativum & ++ & ++ & ++ \\
\hline Vaal & Vicia faba & + & + & + \\
\hline Black Urad & Lens culinaris var. & - & - & - \\
\hline Chana [Green] & Cicer arientinum var. & - & - & - \\
\hline Chana [Kabuli] & Cicer arientinum var. & - & - & - \\
\hline Moong [Green] & Vigna munga & - & - & - \\
\hline
\end{tabular}

Extraction Method 3:- Using Method 3 for extraction, extracts from rajma, black masur, pink masur and corn showed haemagglutination towards $\mathrm{A}, \mathrm{B}$ and $\mathrm{O}$ blood group antigens. The other four species of plant seed extracts did not show any haemagglutination activity (Table 3).

Table 3: Results for qualitative haemagglutination assay using lectins extracted by Method 2. '+' sign is indicative of positive haemagglutination, ' ++ ' and ' +++ ' signs are indicative of relatively greater haemagglutination, '-' sign is indicative of negative haemagglutination.

\begin{tabular}{|c|c|c|c|c|}
\hline \multicolumn{5}{|c|}{ Qualitative analysis of haemagglutination by lectins extracted by Method 3 } \\
\hline Common name & Scientific name(ref.13) & Blood Group A & Blood Group B & Blood Group O \\
\hline Kulith & Dolichos biflorus & - & - & - \\
\hline Rajma & Phaseolus vulgaris var. & ++ & ++ & ++ \\
\hline Masur [Black] & Lens culinaris var. & ++ & ++ & ++ \\
\hline Masur [Pink] & Lens culinaris var. & + & + & + \\
\hline Corn & Zea mays & ++ & ++ & ++ \\
\hline Methi & Trigonella foenum-graecum & - & - & - \\
\hline Sem & Vicia faba & - & - & - \\
\hline Soya bean & Glycine max & - & - & - \\
\hline
\end{tabular}

Lectin from kulith could be extracted using only Method 2 as observed in the qualitative haemagglutination assay (Tables 1, 2, and 3). On changing the $\mathrm{pH}$ of the buffer in Method 3 from $\mathrm{pH} 2.2$ to $\mathrm{pH}$ 8.2, the kulith extract showed positive haemagglutination reaction. The solution in extraction method 2 contains $0.15 \mathrm{M} \mathrm{NaCl}$. This salt seems to be most effective in extracting lectin from kulith probably by having no interfering ions in it. For all further studies, method 2 was used to prepare crude extracts of lectin from kulith, and method 3 was used to prepare extracts from rajma. 
Human red blood cells possessing the A antigen can be broadly subdivided into two main subgroups namely A1 and A2 based on their reaction with A1 lectin (Lee et., al 1983). To determine the specificity of the kulith lectin extract, its haemagglutination property was tested against blood from nine individuals known to be of blood group A (Table 4). The results show that the lectin extract did not agglutinate RBCs from individuals 1 and 2 despite being blood group A (Table 4). Hence, it is possible that these individuals could be of type A2, since kulith is known to contain A1-specific lectin (Nance, 1986).

Table 4: Test of kulith lectin extract for haemagglutination with blood from 9 individuals of type A. (+) indicates positive haemagglutination, whereas (-) indicates no agglutination reaction.

\begin{tabular}{|c|c|c|}
\hline \multicolumn{3}{|c|}{ Blood samples (type A) used for qualitative haemagglutination } \\
assay
\end{tabular}

Quantitative Analysis of Haemagglutination Activity:-

Quantitiative analysis of haemagglutination between $\mathrm{ABO}$ blood group antigens and extracted lectins was carried out. The Haemagglutination Unit (HU) for the rajma lectin extract was found to be 64, and for the kulith extract it was observed to be 8 , indicating a higher concentration of lectins extracted from rajma as compared to kulith.

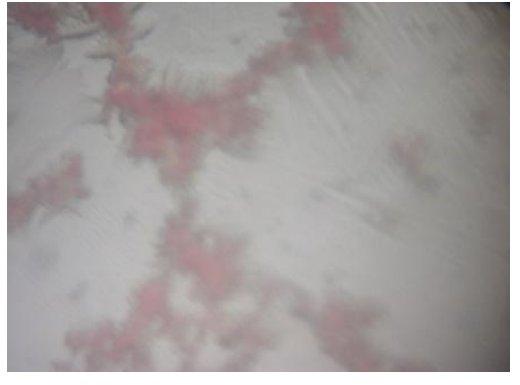

Figure 1: Qualitative assay showing positive haemagglutination..

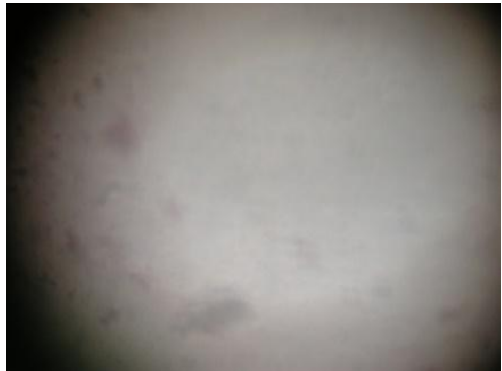

Figure 2: Qualitative assay showing negative haemagglutination.

\section{Effect of Temperature on Rajma Lectin Stability:-}

The effect of temperature on lectin stability was determined by measuring hemagglutinating activity of the incubated lectin extract at increasing temperatures $\left(4^{\circ} \mathrm{C}, 35^{\circ} \mathrm{C}, 55^{\circ} \mathrm{C}, 100^{\circ} \mathrm{C}\right)$ for $30 \mathrm{~min}$. Positive hemagglutination was observed at temperatures $4^{\circ} \mathrm{C}$ and $35^{\circ} \mathrm{C}$ and no reactivity was seen at $55^{\circ} \mathrm{C}$ and above (Table 5). Since lectins are glycoproteins by nature, they could have been denatured at higher temperatures.

Table 5: Effect of temperature on the haemagglutination activity of rajma lectin extract. '+' sign is indicative of positive haemagglutination and the "-" sign is indicative of negative haemagglutination.

\begin{tabular}{|c|c|c|c|c|}
\hline \multicolumn{5}{|c|}{ Effect of temperature on haemagglutination activity of rajma lectin extract } \\
\hline Temperature $\rightarrow$ & $\mathbf{4}^{\circ} \mathbf{C}$ & $\mathbf{3 5}^{\circ} \mathbf{C}$ & $\mathbf{5 5}^{\circ} \mathbf{C}$ & $\mathbf{1 0 0}^{\circ} \mathbf{C}$ \\
\hline $\begin{array}{c}2 \mathrm{~mL} \text { Rajma Extract }+ \\
\text { 2mL of } 4 \% \mathrm{RBC} \\
\text { suspension }\end{array}$ & + & + & - & - \\
\hline
\end{tabular}


Effect of pH on Rajma and Kulith Lectin Extract:-

Hemagglutination activity of these extracts was checked at different $\mathrm{pH}$. It was observed that rajma lectin extract retained its hemagglutinating activity through a range of $\mathrm{pH}$ from acidic to alkaline but the kulith extract lost activity under acidic conditions (Table 6).

Table 6: Effect of $\mathrm{pH}$ on haemagglutination activity of kulith and rajma lectin extract. '+' sign is indicative of positive haemagglutination and the "-" sign is indicative of negative haemagglutination.

\begin{tabular}{|c|c|c|c|c|}
\hline \multicolumn{5}{|c|}{ Effect of $\mathbf{p H}$ on haemagglutination activity of the extracts } \\
\hline Seed / pH & $\mathbf{2 . 2}$ & $\mathbf{5 . 0}$ & $\mathbf{7 . 0}$ & $\mathbf{8 . 2}$ \\
\hline Rajma & + & + & + & + \\
\hline Kulith & - & - & + & + \\
\hline
\end{tabular}

\section{Hapten-Inhibition by Kulith and Rajma Lectin Extracts:-}

Hapten-inhibition assay was carried out to investigate if certain mono and disaccharides, polysaccharides or combinations of sugars could inhibit haemagglutination observed between ABO blood group antigens and the corresponding lectin extract. The results shown in Table 7 for kulith extract indicate that either the lectin had no specificity to the sugar, or the concentration of the extracted lectin was too high to show inhibition. The findings summarized in Table 8 for the rajma lectin extract showed inhibition by $\mathrm{N}$-acetyl galactosamine, indicating a specificity for the sugar. Hence, the rajma lectin can be classified in group 2 (Damjanov, 1987).

Table 7: Effect of increasing concentrations of different sugars on the haemagglutination activity of lectin from kulith. ' + ' sign is indicative of positive haemagglutination.

\begin{tabular}{|c|c|c|c|c|c|}
\hline \multicolumn{7}{|c|}{ Hapten-inhibition assay } \\
\hline $\begin{array}{c}\text { Sugar / } \\
\text { Concentration }\end{array}$ & $\mathbf{0 . 5 M}$ & $\mathbf{0 . 2 5} \mathrm{M}$ & $\mathbf{0 . 1 2 5} \mathrm{M}$ & $\mathbf{0 . 0 6 2 5} \mathrm{M}$ & $\mathbf{0 . 0 3 1 2 5} \mathrm{M}$ \\
\hline D-Galactose & + & + & + & + & + \\
\hline D-Glucosamine & + & + & + & + & + \\
\hline Maltose & + & + & + & + & + \\
\hline Fructose & + & + & + & + & + \\
\hline Sucrose & + & + & + & + & + \\
\hline Glucose & + & + & & & + \\
\hline
\end{tabular}

Table 8: Effect of increasing concentrations of combinations of different sugars on the haemagglutination activity of rajma lectin extract. '+' sign is indicative of positive haemagglutination, '-' sign is indicative of negative haemagglutination and 'N.D.' indicates that the test was not performed at the corresponding concentration.

\begin{tabular}{|c|c|c|c|c|}
\hline \multicolumn{5}{|c|}{ Hapten-inhibition assay } \\
\hline Sugar / Concentration & $\mathbf{0 . 5 M}$ & $\mathbf{0 . 2 5 M}$ & $\mathbf{0 . 0 5 M}$ & $\mathbf{0 . 0 2 5 M}$ \\
\hline Fucose & + & N.D. & + & N.D. \\
\hline Fucose + Glucosamine & N.D. & + & N.D. & + \\
\hline Fucose $+\mathrm{CaCl}_{2}$ & + & N.D. & + & N.D. \\
\hline N-Acetyl galactosamine & - & N.D. & + & N.D. \\
\hline
\end{tabular}

\section{Protein Estimation:-}

Crude extracts from kulith had $14 \mathrm{mg} / \mathrm{mL}$ of protein, whereas that in the rajma crude extract was $20 \mathrm{mg} / \mathrm{mL}$. Method 3 used for extraction from rajma gave a higher yield of protein as compared to the extraction method 2 used for kulith. The protein concentration in the Rajma extract after $25-50 \%$ ammonium sulphate fractionation was found to be $545 \mu \mathrm{g} / \mathrm{mL}$ and that in the $50-75 \%$ fraction was found to be $158 \mu \mathrm{g} / \mathrm{mL}$, indicating partial purification of the proteins. 


\section{Haemagglutination activity after ammonium sulphate fractionation of Rajma extract:-}

The various fractions were checked for haemagglutination activity with Blood Group A, B and O. Positive haemagglutination was found exclusively in fractions: $50-75 \%$ and $75-90 \%$ (Table 9). Fraction $25-50 \%$ did not show any haemagglutination activity indicating that the lectin was absent in this fraction. It was, hence, decided to use the $50-75 \%$ fraction of the rajma extract for quantitative haemagglutination assay. The quantitative HU was found to be 64 , which was the same as that obtained with the crude extracts. Hence, most of the lectin is present in the $50-75 \%$ fraction.

Table 9: Haemagglutination activity of rajma dialysates post ammonium sulphate fractionation. '+' sign is indicative of positive haemagglutination and "- sign is indicative of negative haemagglutination.

\begin{tabular}{|c|c|c|c|}
\hline \multicolumn{3}{|c|}{ Hemagglutination activity of ammonium sulphate fractions } \\
\hline Fraction & Blood Group A & Blood Group B & Blood Group O \\
\hline $0-25 \%$ & - & - & - \\
\hline $25-50 \%$ & - & - & - \\
\hline $50-75 \%$ & + & + & + \\
\hline $75-90 \%$ & + & + & + \\
\hline
\end{tabular}

\section{Protein Separation by SDS-PAGE:-}

A preliminary analysis of proteins in the various extracts from kulith and rajma were done using SDS-PAGE (Fig. 5). The results show several protein bands for the crude extracts and in the ammonium sulphate fractions. Lectinspecific protein band could not be identified from the SDS-PAGE profile. Further purification using affinity chromatography will have to be done to obtain purified lectin from the samples.

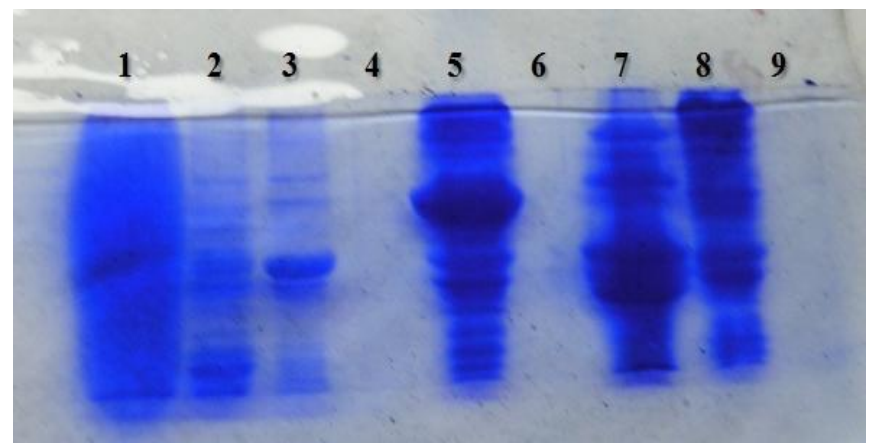

Figure 5: Separation of lectins from rajma and kulith extracts by SDS-PAGE. Lane 1: BSA; Lane 2: Egg albumin; Lane 3: 25-50\% rajma fraction; Lane 4: 50-75\% rajma fraction; Lane 5: 75-90\% rajma fraction; Lane 6: 1:10 diluted rajma extract; Lane 7: Undiluted Rajma extract; Lane 8: Undiluted kulith extract; Lane 9: Kulith extract diluted $1: 10$.

\section{Discussion:-}

A wide variety of lectins derived from seeds, algae, snails, eels, and clams have been demonstrated to agglutinate respective types of erythrocytes. Seeds particularly those of Leguminosae, yield extracts that can be used for typing erythrocytes. In the present study, hemagglutination activity was detected in 10 out of the 21 seed extracts. Lectin extracted only from kulith showed specific agglutination with blood group A, whereas the other lectin extracts did not show any specificity towards the $\mathrm{ABO}$ blood group antigens. Physical and chemical characterization was limited to lectins from rajma and kulith, as rajma yielded instant and maximum haemagglutination and kulith because of its specificity for blood group A antigen. The rajma lectin was stable at both acidic and alkaline $\mathrm{pH}$, where as the kulith lectin was inactive at acidic $\mathrm{pH}$. Both the lectins were inactivated at temperatures above $55 \mathrm{C}$, probably due to its glycoprotein nature. In hapten-inhibition tests, kulith lectin did not show any specificity towards the sugars tested, but rajma lectin was specific for $\mathrm{N}$ acetyl-galactosamine.

There are two major serotypes known within blood group A - A1 and A2, which can be differentiated using Dolichos biflorus lectin. Since the Kulith extract did not show reactivity towards two blood type A samples, it is possible that the extract contains A1- specific lectin. Hence, the blood group of these individuals could be of subtype A2. This study is probably the first report of A1 specific lectin from Indian variety of Dolichos biflorus. 
This confirms the known data of A1 specificity of Dolichos biflorus lectin reported from other parts of the world (Sharon and Lis., 2004).

In conclusion, lectins purified from kulith could be used to identify A1 blood group since commercial blood typing reagents do not discriminate between subtypes A1 and A2. This would then probably be the only known method of differentiating between subtypes A1 and A2 resulting in greater accuracy during blood transfusions.

\section{Acknowledgement:-}

The research project was supported by a minor research grant from the University of Mumbai to Dr. Radiya PachaGupta in 2010. The authors acknowledge the Department of Life Sciences and Biochemistry, St. Xavier's College, Mumbai, for having permitted the use of the laboratory for the experiments.

\section{References:-}

1. Ali, M.A., Sayeed, M.A. and Absar, N. (2013). Purification and characterization of three lectins extracted from Cassia fistula seeds and effect of physical and chemical agents on their stability. J Chin Chem Soc 51(3): $647-654$.

2. Ceccatto V.M., Cavada, B.S., Nunes, E.P., Nogueira, N.A.P., Grangeiro, M.B., Moreno, F.B.M.B., Teixeira, E.H., Sampaio, A.H., Alves, M.A.O., Ramos, M.V., Calvete, J.J. and Grangeiro, T.B. (2002). Purification and partial characterization of a lectin from Canavalia Grandiflora Benth. Seeds. Prot Pep Lett 9(1): $67-73$.

3. Damjanov, I. (1987). Biology of disease. Lectin cytochemistry and histochemistry. Lab Invest 57: 5 - 20.

4. Da Silva, A.L.C., Horta, A.C.G., Moreira and R.A. (2001). Isolation and partial characterization of a lectin from Bauhinia pentandra (bong) vog. ex. Steua. Rev Bras Fisiol Veg 13(3): 262 - 269.

5. Eshdat, Y., Ofek, I., Yashouv-Gan, Y., Sharon, N. and Mirehnan, D. (1978). Isolation of a mannose-specific lectin from Escherichia coli and its role in the adherence of the bacteria to epithelial cells. Biochem Biophys Res Commun 85: $1551-1560$.

6. Etzler, M. E. (1986). Distribution and function of plant lectins, p. 371 - 435. In I. E. Liener, N. Sharon, and I. J. Goldstein (ed.), The lectins, properties, functions, and applications in biology and medicine. Academic Press, Inc., Orlando, Fla.

7. Grant, G., More, L.J., McKenzie, N.H., Dorward, P.M., Buchan, W.C., Telek, L. and Pusztai, A. (1995). Nutritional and haemagglutination properties of several tropical seeds. J Agri Sci 124(3): 437 - 445.

8. Ingram, G.A. and Molyneux, D.H. (1988). Sugar specificities of anti-human ABO(H) blood group erythrocyte agglutinins (lectins) and haemolytic activity in the haemolymph and gut extracts of three Glossina species. Insect Biochem 18(3): $269-279$.

9. Lee H.H., Rouger P., Germain C., Muller A. \& Salmon C. (1983). The production and standardisation of monoclonal antibodies as AB blood group typing reagents, Symposium of International Association of Biological standardisation on monoclonal antibodies.

10. Lis, H., and Sharon, N. (1986). Application of lectins, p. 293 - 370. In I. E. Liener, N. Sharon, and I. J. Goldstein (ed.), The lectins: properties, functions and applications in biology and medicine. Academic Press, Inc., Orlando, Fla.

11. Lu, B., Zhang, B., Qi, W., Zhu, Y., Zhao, Y., Zhou, N., Sun, R., Bao, J. and Wu, C. (2014). Conformational study reveals amino acid residues essential for hemagglutinating and anti-proliferative activities of Clematis montana lectin. Acta Biochim Biophys Sin 46(11): 923 - 934.

12. Mandrell, R.E., Griffis, J.M. and Macher, B.A. (1988). Lipooligosaccharides (LOS) of Neisseria gonorrhoeae and Neisseria meningitidis have components that are immunochemically similar to precursors of human blood group antigens. Carbohydrate sequence specificity of the mouse monoclonal antibodies that recognize crossreacting antigens on LOS and human erythrocytes. J Exp Med 168(1): 107 - 126.

13. Nance, S. T. (1986). Serology of the ABH and Lewis blood group systems, p. 57 - 81. In M. E. Wallace and F. L. Gibbs (ed.), Blood group systems: ABH and Lewis. Associated Blood Banks, Arlington, Va.

14. Pereira, P.R., Winter, H.C., Vericimo, M.A., Meagher, J.L., Stuckey, J.A., Goldstein, I.J., Paschoalin, V.M.F. and Silva, J.T. (2015). Structural analysis and binding properties of isoforms of tarin, the GNA-related lectin from Colocasia esculenta. Biochim Biophys Acta 1854(1): 20 - 30.

15. Sambrook, J. and Russell, W.D. (2001). Molecular Cloning: A Laboratory Manual (Volume 1), CSHL Press, USA, $1877-2007$.

16. Sharon, N. and Lis, H. (2004). History of lectins: from haemaglutinins to biological recognition molecules. Glycobiology 14(11): 53R - 62R.

17. Sharon, N. and Lis, H. (1972). Lectins: Cell-agglutinating and sugar-specific proteins. Science 177(4053): 949 959.

18. Slifkin, M. and Doyle, R.J. (1990). Lectins and their application to clinical microbiology. Cli Micro Rev 3(3): 197 218. 